\title{
Runoff prediction under different climate scenarios in the source region of the Yellow River
}

\author{
F. F. Yuan ${ }^{1}$, Z. C. $\mathrm{Hao}^{2}$ \& L. Zhang ${ }^{1}$ \\ ${ }^{I}$ Division of Water Resources Engineering, Lund University, Sweden \\ ${ }^{2}$ State Key Laboratory of Hydrology-Water Resources and \\ Hydraulic Engineering, Hohai University, China
}

\begin{abstract}
Climate change has great effect on water resources in the source region of the Yellow River, which affects agricultural productivity, industrial water supply and wildlife management in the whole river basin. The hydrologic characteristics of precipitation, temperature and runoff in the source region of the Yellow River are analyzed using the long-term observed data from 1961 to 2010. The trend of runoff is predicted by the multivariate linear regression method under different climate scenarios. Reasons for the changing runoff are explored from the climate change and human activities perspective.

Keywords: the source region of the Yellow River, runoff, climate change.
\end{abstract}

\section{Introduction}

Climate change has great effect on water resources, which affects agricultural productivity and industrial water supply. The 100-year linear trend (1906-2005) of the global surface average temperature is $0.74[0.56 \text { to } 0.92]^{\circ} \mathrm{C}$, and the linear warming trend over the 50 years from 1956 to $2005\left(0.13[0.10 \text { to } 0.16]^{\circ} \mathrm{C}\right.$ per decade) is nearly twice that for the 100 years from 1906 to 2005 (Parry et al. [1]). Global warming could intensify the hydrological cycle, which will redistribute the water resources at spatial and temporal scales. Besides, melting glaciers will increase flood risk during the rainy season, and strongly reduce dryseason water supplies.The future water resources status will depend on the effect of climate change and human activities. It is a great challenge to evaluate these 
impacts due to many reasons, such as population growth, economic development, improvement of technologies and water management policy.

The source region of the Yellow River occupies $16.2 \%$ of the whole basin area and contributes about $35 \%$ of the total water yield in the Yellow River basin (Chen and Liu [2]). There are no large dams or irrigation projects in this area, and human activities can be ignored because of less population, so the runoff could be thought as a kind of natural response to climate change. The temperature in this area has increased obviously from the 1980s, especially during the last ten years. The runoff has been decreasing continually since the end of the 1980s, which greatly affected the agriculture, flooding and the ecological environment in this area. This obvious change causes lots of attention. This study analyzes the hydrologic changing characteristics using the up-to-date data and predicts the runoff in the source region of the Yellow River under different climate scenarios, which give us a guideline to manage the water resources efficiently in this river basin and a better understanding how climate change affects the water resources.

\section{Study area and data}

The source region of the Yellow River is located in the northeast Qinghai-Tibet Plateau between $32^{\circ} 12^{\prime}-35^{\circ} 48^{\prime} \mathrm{N}$ and $95^{\circ} 50^{\prime}-103^{\circ} 28^{\prime} \mathrm{E}$, and includes the region above the Tangnaihai Hydrologic Station. The area is $12.2 \times 10^{4} \mathrm{~km}^{2}$ and has great elevation difference from $2546 \mathrm{~m}$ in the east to $6282 \mathrm{~m}$ in the west. It is called the 'water tower' of the Yellow River. Around $80 \%$ of the region is covered by grassland. Eling and Zhaling are the two largest lakes in the west region, covered $610 \mathrm{~km}^{2}$ and $550 \mathrm{~km}^{2}$, respectively (Hu et al. [3]).

The daily precipitation and temperature data from 1961 to 2010 are used in this study, which are collected from ten meteorological stations including Xinghai, Tongde, Zeku, Henan, Maduo, Dari, Jiuzhi, Maqu, Ruoergai and Hongyuan.

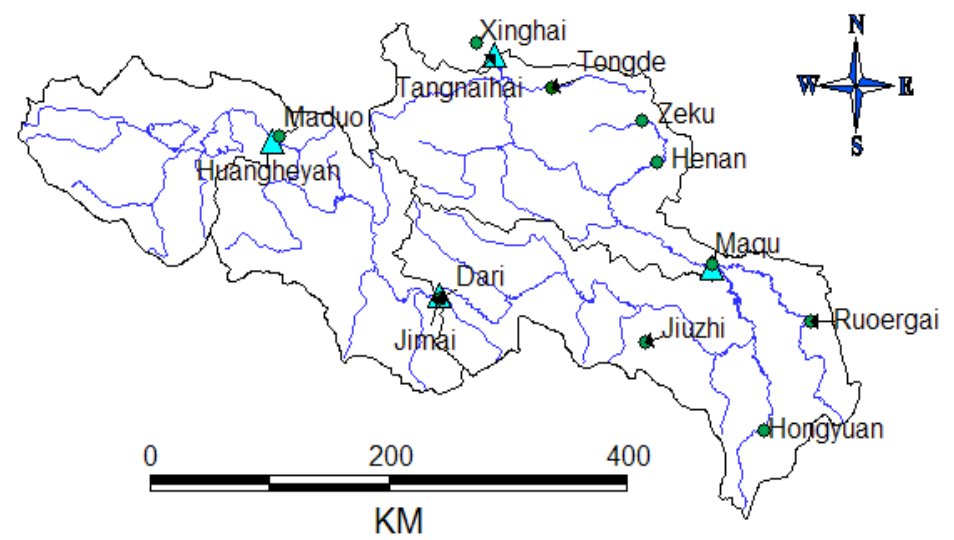

Figure 1: The location of hydro-climatic stations and river network in the source region of the Yellow River. 
Daily streamflow data from four hydrologic stations located in the mainstream, including Huangheyan, Jimai, Maqu and Tangnaihai, are used to analyse the runoff change. Tables 1 and 2 show the summary characteristics of hydro-climatic stations in the study area. The precipitation and temperature for this area are calculated by arithmetic average method.

Table 1: $\quad$ Summary of characteristics of ten meteorological stations.

\begin{tabular}{|c|c|c|c|c|c|}
\hline Station & $\begin{array}{c}\text { Altitude } \\
(\mathrm{m})\end{array}$ & $\begin{array}{c}\text { Longitude } \\
\left({ }^{\circ} \mathrm{E}\right)\end{array}$ & $\begin{array}{c}\text { Latitude } \\
\left({ }^{\circ} \mathrm{N}\right)\end{array}$ & $\begin{array}{c}\text { Annual } \\
\text { Precipitation } \\
(\mathrm{mm} / \mathrm{a})\end{array}$ & $\begin{array}{c}\text { Annual } \\
\text { Temperature } \\
\left({ }^{\circ} \mathrm{C}\right)\end{array}$ \\
\hline Xinghai & 3323 & 99.98 & 35.58 & 365.3 & 1.44 \\
\hline Tongde & 3289 & 100.39 & 35.16 & 411.2 & 0.67 \\
\hline Zeku & 3663 & 101.28 & 35.02 & 418.1 & -2.16 \\
\hline Henan & 3500 & 101.36 & 34.44 & 583.9 & 0.31 \\
\hline Maduo & 4272 & 98.13 & 34.55 & 318.5 & -3.63 \\
\hline Dari & 3967 & 99.65 & 33.75 & 551.8 & -0.78 \\
\hline Jiuzhi & 3629 & 101.48 & 33.43 & 744.7 & 0.71 \\
\hline Maqu & 3471 & 102.08 & 34.00 & 589.2 & 1.58 \\
\hline Ruoergai & 3440 & 102.97 & 33.58 & 649.7 & 1.20 \\
\hline Hongyuan & 3492 & 102.55 & 32.80 & 747.1 & 1.52 \\
\hline
\end{tabular}

Table 2: $\quad$ Streamflow characteristics of four hydrologic stations.

\begin{tabular}{|c|c|c|c|c|c|}
\hline Station & $\begin{array}{c}\text { Altitude } \\
(\mathrm{m})\end{array}$ & $\begin{array}{c}\text { Longitude } \\
\left({ }^{\circ} \mathrm{E}\right)\end{array}$ & $\begin{array}{c}\text { Latitude } \\
\left({ }^{\circ} \mathrm{N}\right)\end{array}$ & $\begin{array}{c}\text { Mean Discharge } \\
\left(\mathrm{m}^{3} / \mathrm{s}\right)\end{array}$ & $\begin{array}{c}\text { Record } \\
\text { Length }\end{array}$ \\
\hline Huangheyan & 4221 & 98.17 & 34.88 & 20.2 & $1956-2009$ \\
\hline Jimai & 3969 & 99.65 & 33.77 & 129.3 & $1958-2009$ \\
\hline Maqu & 3471 & 102.08 & 33.97 & 455.2 & $1959-2009$ \\
\hline Tangnaihai & 2546 & 100.15 & 35.50 & 631.5 & $1956-2009$ \\
\hline
\end{tabular}

\section{Hydrologic characteristics}

\subsection{Temperature}

The temperature continued to rise from 1960s and especially had a strong increasing trend during the last ten years, and it has the maximum value of $1.71^{\circ} \mathrm{C}$ in 2010 (see Figure 2). The temperature change in the source region of the Yellow River has the same trend with the whole Qinghai-Tibet Plateau area (Hao and Wang [4]). Figure 3 shows monthly temperature variation using the data from 1961 to 2010 . The maximum value is $10.42^{\circ} \mathrm{C}$ in July and the minimum value is $-11.84^{\circ} \mathrm{C}$ in January. The temperature is lower than zero centigrade degree around half period every year. 


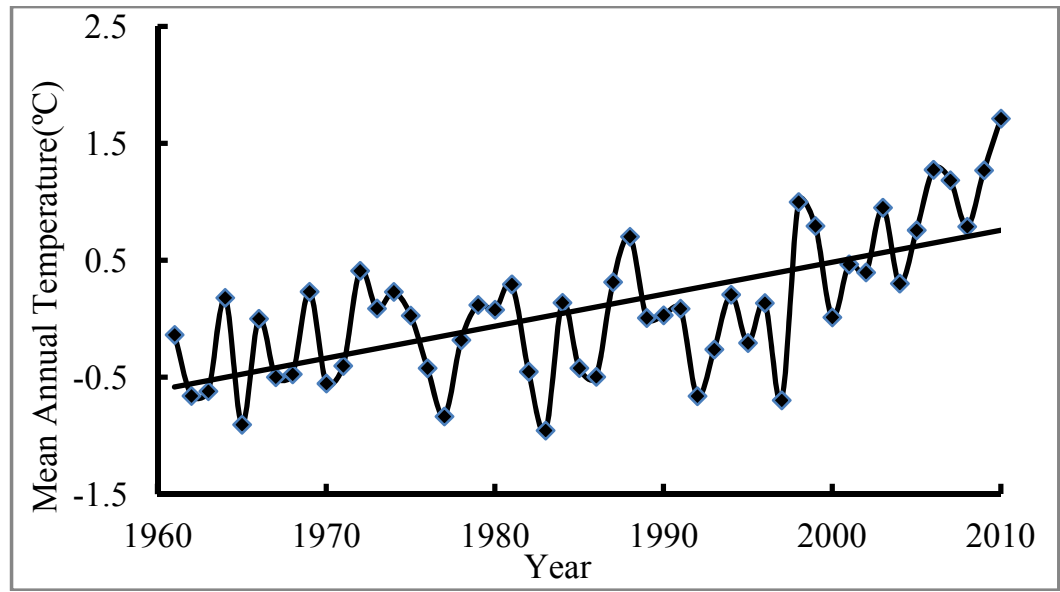

Figure 2: $\quad$ The mean annual temperature in the study area.

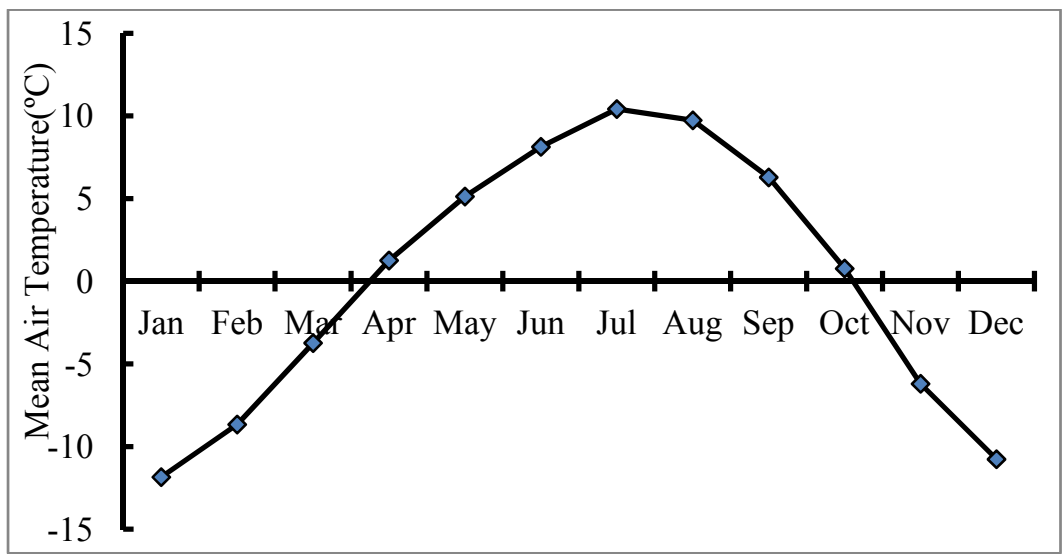

Figure 3: $\quad$ The mean air temperature in the study area from 1961 to 2010.

\subsection{Precipitation}

During the period of 1961-2010, the mean annual precipitation has a slight downward trend in the source region of the Yellow River (see Figure 4). The basin average precipitation from 1961 to 2009 is $541.7 \mathrm{~mm}$. The maximum value is $691.5 \mathrm{~mm}$ in 1967 , and the minimum value is $417.4 \mathrm{~mm}$ in 2002 . The precipitation has a great decreasing trend in the 1990s. The basin average precipitation has decreased by $28.2 \mathrm{~mm}$ in the 2000 s compared with the $1960 \mathrm{~s}$, and the decreasing rate was $5.64 \mathrm{~mm} / 10$ years. The monthly precipitation varies during the year (see Figure 5). It is $108.64 \mathrm{~mm}$ in July but only $2.15 \mathrm{~mm}$ in January. The less precipitation will reduce the runoff in this area. 


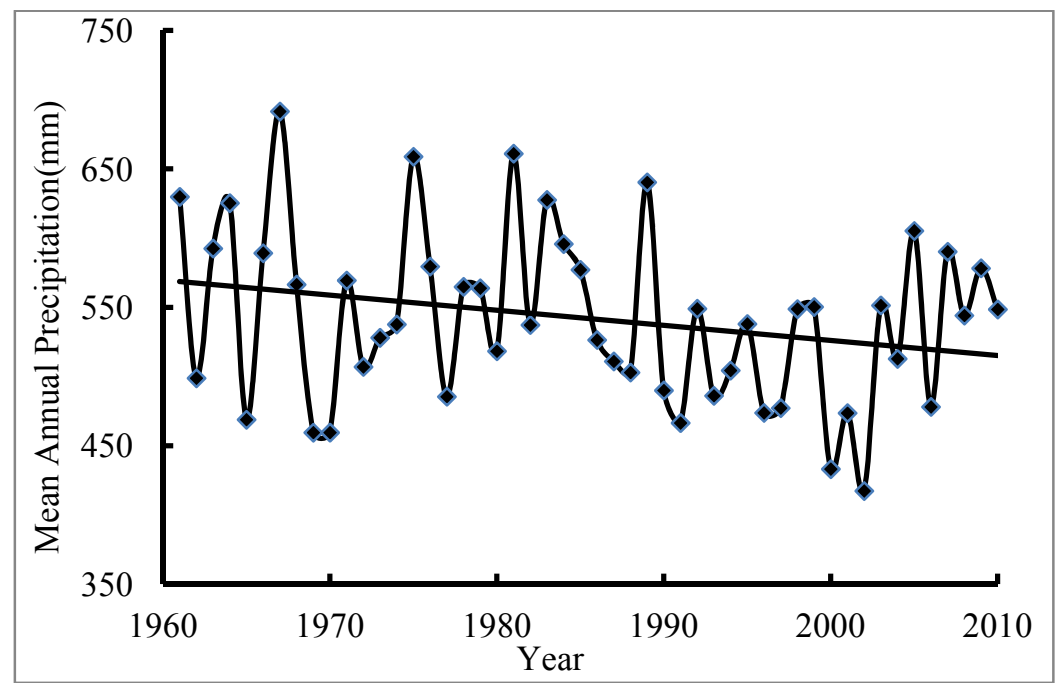

Figure 4: The mean annual precipitation in the study area.

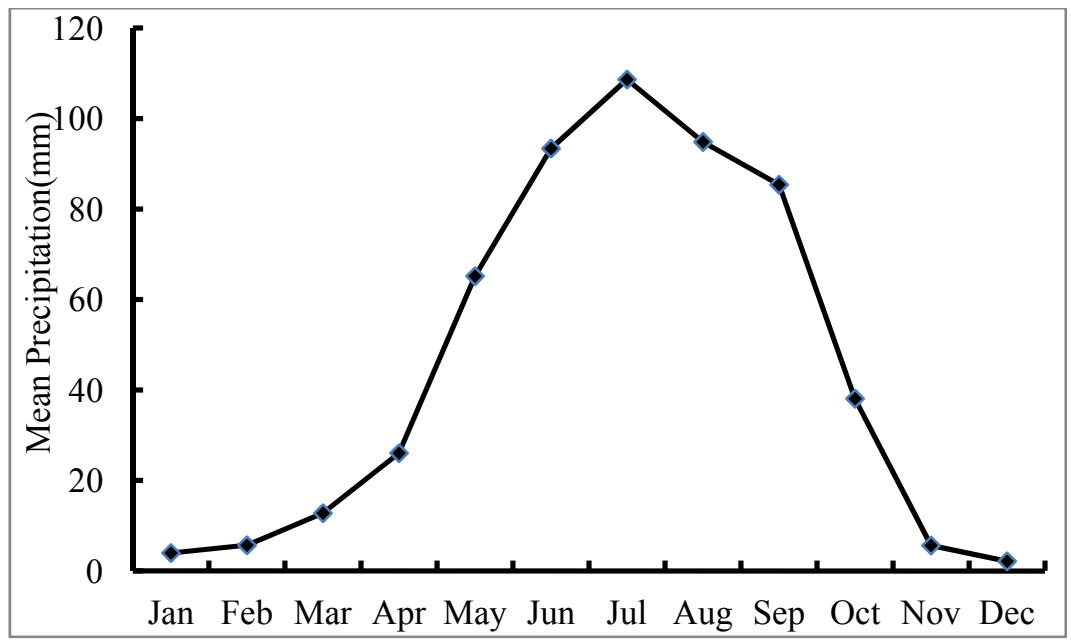

Figure 5: $\quad$ The monthly precipitation in the study area from 1961 to 2010.

\subsection{Runoff}

The runoff didn't change a lot in the 1960s and 1970s for every station in this area. It reached the peak in the 1980s. The discharge in every hydrologic station decreased significantly in the 1990s (see Figure 6). The runoff is mainly concentrated during the flood season (June-October), which is corresponding to the precipitation. The data from Tangnaihai and Maqu hydrologic station showed 
the same trend both in decadal mean discharge and in annual discharge (see Figure 7). The decadal mean discharge at Tangnaihai hydrologic station had decreased $210 \mathrm{~m}^{3} / \mathrm{s}$ in the 2000 s compared with the 1980 s, and it decreased by $27.5 \%$. The runoff is mainly influenced by the climate factors rather than human activities due to the less population in this area.

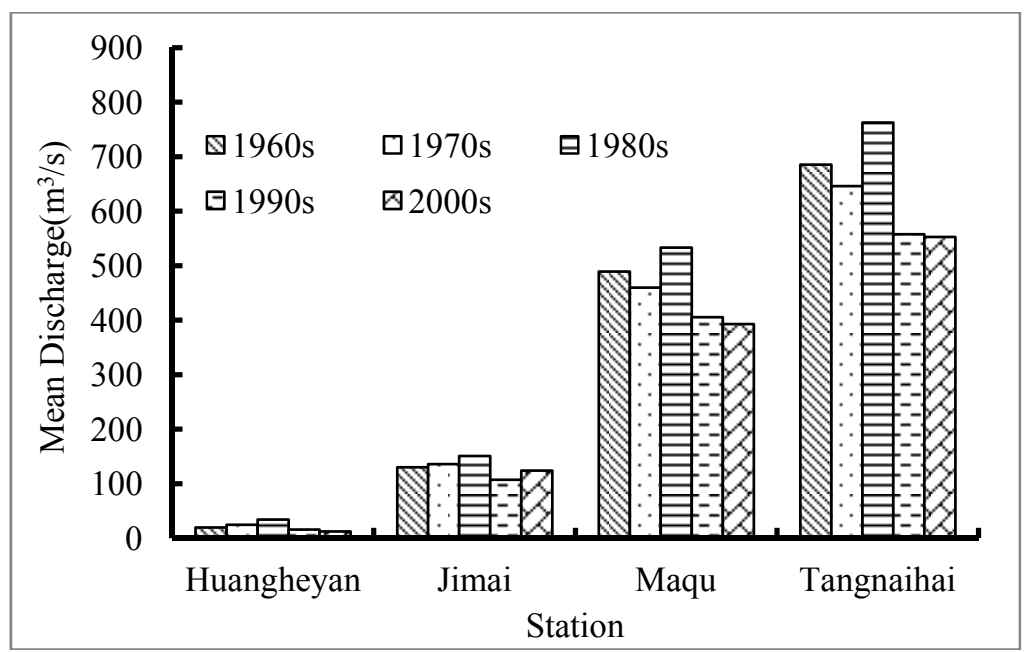

Figure 6: The decadal mean discharge at four hydrologic stations.

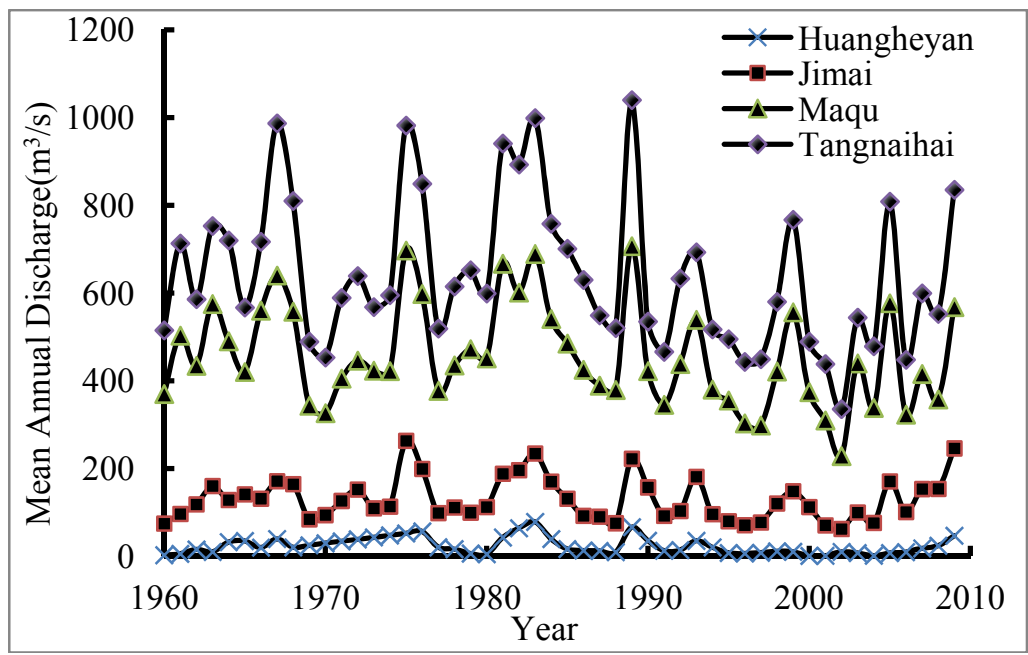

Figure 7: The mean annual discharge at four hydrologic stations. 


\section{The response of runoff to climate change}

\subsection{The future climate scenarios}

Increased concentration of greenhouse gases changed the component of atmosphere, causing change in temperature and precipitation and other hydrologic variables (Houghton et al. [5]). The present and future climate scenarios simulated by global atmospheric general circulation models (GCMs) has been published by the IPCC data center. Such climate models are becoming increasingly sophisticated, but they do include uncertainty due to the limited understanding of climate system and computing power (Trenberth [6]). Besides, we cannot make use of the climate model output directly for hydrological prediction because of the scale difference.

The future temperature in the source region of the Yellow River will increase about $1.5^{\circ} \mathrm{C}$ in the $21^{\text {st }}$ century simulated by various climate models (Parry et al. [1]). We need to provide the future climate scenarios as the input for the runoff prediction. In this paper, we use the suppositional climate scenarios. The temperature scenario has 5 kinds of change based on the basin average value from 1961 to 2009 , which increases by $+0.3^{\circ} \mathrm{C},+0.6^{\circ} \mathrm{C},+0.9^{\circ} \mathrm{C},+1.2^{\circ} \mathrm{C}$ and $+1.5^{\circ} \mathrm{C}$. The precipitation scenario has 7 kinds of change based on the basin average value from 1961 to 2009 , which is changed by $-15 \%,-10 \%,-5 \%, 0 \%$, $5 \%, 10 \%, 15 \%$. There are 35 kinds of combined suppositional scenarios.

\subsection{Runoff prediction}

The hydrologic cycle is quite complex. The runoff can be predicted by the statistical method under the climate scenarios. We build up the multivariate linear regression formula based on the long-term data series from 1961 to 2009, including precipitation, temperature and runoff depth in the source region of the Yellow River. The formula is as follows:

$$
R(P, T)=-154+0.59 P-12.17 T
$$

$\mathrm{R}, \mathrm{P}$ and $\mathrm{T}$ represent runoff depth, basin average precipitation and average temperature, respectively. Table 3 shows the regression statistics results.

Table 3: $\quad$ The regression statistics results.

\begin{tabular}{|c|c|c|c|}
\hline \multicolumn{4}{|c|}{ Regression Statistics } \\
\hline Multiple R & R Square & $\begin{array}{c}\text { Adjusted R } \\
\text { Square }\end{array}$ & $\begin{array}{c}\text { Standard } \\
\text { Error }\end{array}$ \\
\hline 0.86 & 0.75 & 0.73 & 22.71 \\
\hline
\end{tabular}

The results from table 4 show that the increasing runoff is corresponding to the increasing of precipitation and decreasing of temperature. Generally, the climate in the source region of the Yellow River is considered to be the "warm- 
aridness" scenario, which means the temperature will increase and the precipitation will be the opposite way. The runoff depth will reduce by $65.83 \mathrm{~mm}$ under the most 'warm-aridness' scenario.

Table 4: The response of runoff to different climate scenarios.

\begin{tabular}{|c|c|c|c|c|c|}
\hline$\Delta \mathrm{P}^{\Delta \mathrm{T}}$ & +0.3 & +0.6 & +0.9 & +1.2 & +1.5 \\
\hline$-15 \%$ & -51.22 & -54.87 & -58.52 & -62.18 & -65.83 \\
\hline$-10 \%$ & -35.17 & -38.82 & -42.47 & -46.12 & -49.78 \\
\hline$-5 \%$ & -19.12 & -22.77 & -26.42 & -30.07 & -33.72 \\
\hline 0 & -3.06 & -6.72 & -10.37 & -14.02 & -17.67 \\
\hline $5 \%$ & 12.99 & 9.34 & 5.68 & 2.03 & -1.62 \\
\hline $10 \%$ & 29.04 & 25.39 & 21.74 & 18.08 & 14.43 \\
\hline $15 \%$ & 45.09 & 41.44 & 37.79 & 34.14 & 30.48 \\
\hline
\end{tabular}

\section{Conclusions}

This paper analyzed the hydrologic characteristics using the up-to-date data from 1961 to 2010 and predicted the runoff by multivariate linear regression method under different climate scenarios. The conclusions are as following:

(1) The precipitation change varies at different stations because of the temporal and spatial difference, and it has a slight downward trend for the last 50 years in the whole area.

(2) The temperature had increased, especially during the last ten years. This change in the source region of the Yellow River, even in the whole QinghaiTibet Plateau, is corresponding to global warming.

(3) The runoff reached the maximum value in every hydrologic station in the 1980 s, and since then it reduced gradually because of the rising temperature and decreasing precipitation. The decadal mean discharge in every station did not show the same changing trend, and probably due to the mechanism for generating the runoff. The runoff distribution within the year is unbalanced. This situation will easily cause drought and flood. We should pay more attention to the monthly change.

(4) The runoff is predicted under different suppositional climate scenarios. The rising temperature will increase glacier and snow melt, and affect the runoff volume. The runoff is more sensitive to the precipitation change. It could reduce $40 \%$ of the average value under the most "warm-aridness" scenarios.

\section{Acknowledgements}

This research is supported by Key Program of National Natural Science Foundation of China (Grant No. 40830639). The funding for this conference is supported by Ångpanneföreningens Forskningsstiftelse, Sweden. 


\section{References}

[1] Parry, M.L., Canziani, O.F., Palutikof, J.P., Van der linden, P.J. and Hanson, C.E., (eds). Climate Change 2007: Impacts, Adaptation, and Vulnerability. Contribution of Working Group II to the Fourth Assessment Report of the Intergovernmental Panel on Climate Change, Cambridge University Press: Cambridge, UK, 2007.

[2] Chen, L.Q. and Liu,C. M., Changes of runoff components in the source region of the Yellow River during the second half of the twentieth century. Water International, 34(4), pp. 497-507, 2009.

[3] Hu, Y.R., Maskey, S., Uhlenbrook, S. and Zhao, H.L., Streamflow trends and climate linkages in the source region of the Yellow River, China. Hydrological Processes, 25(22), pp. 3399-3411, 2011.

[4] Hao, Z.C. and Wang, J.H., Impact of climate change on runoff in source region of Yellow River. Journal of Glaciology and Geocryology, 28(1), pp. 1-7, 2006.

[5] Houghton, J.T., Jenkins, G. J. and Ephraums, J.J., (eds). Climate Change. The IPCC Assessment, Cambridge University Press, 1990.

[6] Trenberth, K. E., The use and abuse of climate models. Nature, 386(6621), pp. 131-133,1997. 